\title{
Uji Performa Teknik Klasifikasi untuk Memprediksi Customer Churn
}

\author{
Anggito Wicaksono ${ }^{1}$, Anita $^{2}$, Tesa Nur Padilah ${ }^{3}$ \\ Universitas Singaperbangsa Karawang ${ }^{1,2,3}$ \\ anggito.wicaksono17057@student.unsika.ac.id ${ }^{1}$, anita.anita17008@student.unsika.ac.id ${ }^{2}$, \\ tesa.nurpadilah@staff.unsika.ac.id ${ }^{3}$
}

\begin{abstract}
Abstrak - Perkembangan industri telekomunikasi sangatlah cepat, hal ini dapat dilihat dari perilaku masyarakat yang menggunakan internet dalam berkomunikasi. Perilaku ini menyebabkan banyaknya perusahaan telekomunikasi dan meningkatnya internet service provider yang dapat menimbulkan persaingan antar provider. Pelanggan memiliki hak dalam memilih provider yang sesuai dan dapat beralih dari provider sebelumnya yang diartikan sebagai customer churn. Peralihan ini dapat menyebabkan berkurangnya pendapatan bagi perusahaan telekomunikasi sehingga penting untuk ditangani. Tujuan dari penelitian ini yaitu untuk mengetahui algoritme klasifikasi terbaik dan sesuai pada permasalahan customer churn. Penelitian ini dilakukan berdasarkan metode CRISP-DM sebagai alur penelitian dengan menerapkan tiga algoritme klasifikasi yaitu Logistic Regression, Decision Tree, dan Random Forest, yang dibantu dengan metode feature selection yaitu Backward Elimination untuk mengurangi variabel yang tidak signifikan. Hasil dari penelitian ini memperoleh bahwa algoritme Logistic Regression dengan Backward Elimination merupakan algoritme terbaik dengan nilai akurasi sebesar $82,23 \%$, recall $57,22 \%$, dan AUC sebesar 0,853 yang termasuk pada pemodelan good classification.
\end{abstract}

Kata Kunci : Industri Telekomunikasi, Customer Churn, CRISP-DM, Klasifikasi, Backward Elimination

\begin{abstract}
The development of the telecommunications industry is very fast, it can be seen from the behavior of people who use the internet to communicate. This behavior causes the number of telecommunications companies and the increase in internet service provider which can lead to competition between providers. Customers have the right to choose the appropriate provider and can switch from the previous provider which is defined as customer churn. This transition can lead to reduced revenue for telecommunications companies so it is important to handle it. The purpose of this research is to find out the best and suitable classification algorithm for customer churn problems. This research was conducted based on the CRISP-DM method as a research flow by applying three classification algorithms, namely Logistic Regression, Decision Tree, and Random Forest, which was assisted by the feature selection method, namely Backward Elimination to reduce insignificant variables. The results of this study indicate that the Logistic Regression algorithm with Backward Elimination is the best algorithm with an accuracy value of $82.23 \%$, a recall of $57.22 \%$, and an AUC of 0.853 which is included in the good classification modeling.
\end{abstract}

Keywords: Telecommunication Industry, Customer Churn, CRISP-DM, Classification, Backward Elimination

\section{PENDAHULUAN}

Industri telekomunikasi saat ini mengalami perkembangan yang sangat cepat. Hal ini menyebabkan bergesernya perilaku komunikasi masyarakat yang awalnya menggunakan telepon dan short message service (SMS) menjadi telekomunikasi berbasiskan data yang didukung oleh internet (Kementerian Komunikasi dan Informatika, 2018). Perkembangan ini mengakibatkan bertambahnya perusahaan telekomunikasi yang dapat memenuhi kebutuhan masyarakat seperti meningkatnya internet service provider (ISP). Hal ini tentunya juga dapat menimbulkan persaingan yang ketat antar operator ISP (Wardani \& Ariasih, 2019). Persaingan tersebut mengakibatkan setiap operator tidak hanya memperhatikan perkembangan dari produk maupun layanan mereka, akan tetapi juga berfokus terhadap pelanggan, karena dalam hal ini pelanggan dapat memilih operator yang sesuai dengan kebutuhannya yang sewaktuwaktu juga dapat melakukan peralihan (churn). Customer churn merupakan beralihnya pelanggan dari satu provider ke provider lain yang mengacu pada hilangnya pelanggan secara periodik dalam suatu organisasi sehingga dapat menyebabkan berkurangnya pendapatan secara signifikan bagi perusahaan telekomunikasi (Pamina et al., 2019). Hal ini tentunya merupakan suatu masalah bagi perusahaan tersebut. Untuk mempertahankan pelanggannya, perusahaan telekomunikasi harus meningkatkan produk dan layanannya, serta terlebih dahulu mengetahui pelanggan yang memiliki perilaku yang berkemungkinan akan meninggalkan layanan dari perusahaan (Kavitha, G. Kumar, S. Kumar, \& Harish, 2020). Prediksi customer churn merupakan cara untuk mengidentifikasi churners sebelum berpindah, yang dapat dilakukan dengan cara menganalisis data dan menemukan pola yang 
berguna. Hal ini tentunya dapat dilakukan dengan pendekatan data mining (Herawati, Wibowo, \& Mukhlash, 2016).

Data mining merupakan rangkaian proses untuk menambang dan mengolah data menjadi pengetahuan. Terdapat beberapa teknik data mining yang dapat digunakan untuk mengekstrak data menjadi pengetahuan, salah satunya klasifikasi (Drajana, 2019). Teknik klasifikasi merupakan teknik yang dapat memprediksi customer churn (Utami, Shofiana, \& Heningtyas, 2020). Dalam melakukan prediksi, pendekatan ini memerlukan data-data masa lalu yang telah dikumpulkan (Yulianti, 2018).

Pada beberapa kasus mengenai prediksi customer churn, teknik klasifikasi yang umum digunakan yaitu decision tree, rule-based learning, dan neural networks yang terbukti bahwa ketiga algoritme tersebut dapat melakukan prediksi terhadap permasalahan customer churn (Kavitha et al., 2020).

Pada penelitian sebelumnya, melakukan perbandingan terhadap tiga algoritme yaitu random forest, logistic regression, dan XGBoost untuk memprediksi customer churn. Penelitian ini mendapatkan hasil bahwa algoritme random forest memiliki akurasi sedikit lebih tinggi dari dua algorime lainnya (Kavitha et al., 2020). Penelitian lain, menggunakan algoritme decision tree untuk melakukan prediksi terhadap customer churn, selain sering digunakan pada pemodelan klasifikasi, algoritme ini juga mampu dalam memprediksi customer churn (Utami et al., 2020).

Pada penelitian ini, teknik data mining yang digunakan untuk melakukan prediksi customer churn yaitu teknik klasifikasi dengan menerapkan tiga algoritme yaitu logistic regression (LR), decision tree (DT), dan random forest (RF), serta menerapkan metode feature selection pada ketiga algoritme tersebut. Ketiga algoritme yang digunakan dipilih dan disesuaikan dengan kondisi dari dataset yaitu terdapat salah satu atribut yang berfungsi sebagai label atau kelas target. Dataset yang digunakan diambil dari Public Dataset Kaggle (Kaggle, 2018), yang diproses menggunakan bantuan tools RapidMiner.

Berdasarkan hal tersebut, tujuan dari penelitian ini yaitu menerapkan teknik klasifikasi dengan beberapa algoritme yang dipilih, sehingga ditemukan algoritme terbaik yang dapat digunakan untuk memprediksi customer churn.

\section{METODOLOGI PENELITIAN}

Penelitian ini didasarkan pada metode Cross Industry Standard Process for Data Mining (CRISP-DM) sebagai alur penelitian dari awal hingga akhir yang terdiri dari enam tahap seperti pada Gambar 1.

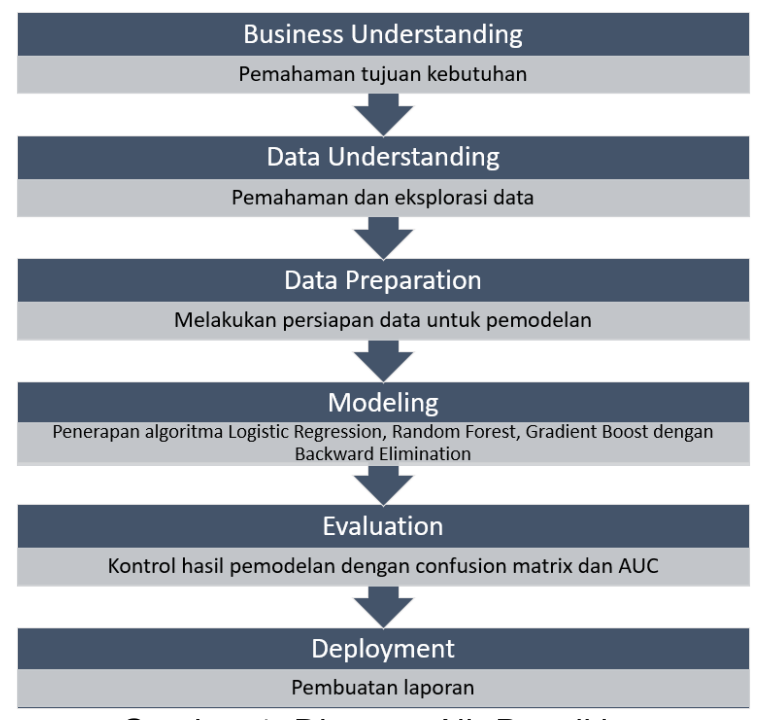

Gambar 1. Diagram Alir Penelitian

\section{Business Understanding (Pemahaman} Bisnis)

Tahap ini merupakan tahap awal untuk mengetahui masalah yang akan diselesaikan guna mencapai tujuan yang diinginkan.

2. Data Understanding (Pemahaman Data)

Tahap ini merupakan tahap pengumpulan data awal yang dipersiapkan untuk diolah dan dimodelkan, serta mendeteksi bagian data yang menarik sebagai hipotesis awal.

3. Data Preparation (Persiapan Data)

Tahap ini meliputi kegiatan yang dilakukan untuk menyiapkan data yaitu pemilihan data, integrasi, serta pembersihan data.

4. Modelling (Pemodelan)

Tahap ini merupakan tahap pemilihan teknik data mining dan algoritme yang akan digunakan dalam penelitian.

5. Evaluation (Evaluasi)

Tahap pengukuran keakuratan hasil dari pemodelan yang dilakukan untuk mengetahui performa dari algoritme yang diterapkan.

6. Deployment (Penyebaran)

Tahap penyusunan laporan berdasarkan pengetahuan yang diperoleh (Khumaidi, 2020).

\section{HASIL DAN PEMBAHASAN}

1. Business Understanding (Pemahaman Bisnis)

Pemahaman bisnis merupakan tahap awal dari metode CRISP-DM (Ramadhan \& Kurniawati, 2020). Hasil dari pemahaman bisnis diubah menjadi rencana awal dan tujuan dilakukannya penelitian. Tujuan dari penelitian ini yaitu melakukan uji perbandingan algoritme klasifikasi yang diterapkan pada dataset pelanggan dari perusahaan telekomunikasi. Perbandingan algoritme ini dilakukan untuk mengetahui algoritme terbaik yang sesuai pada dataset pelanggan perusahaan telekomunikasi. 
2. Data Understanding (Pemahaman Data)

Data awal merupakan dataset yang berisi informasi pelanggan sebuah perusahaan telekomunikasi yang didapat dari situs web Kaggle dengan file berformat csv. Dataset yang didapat yaitu data sampel International Business Machines (IBM) dengan 7043 record dan 21 atribut yang dapat dilihat pada Tabel 1

Setiap baris pada dataset mewakili pelanggan dan setiap kolom berisi atribut yang berupa informasi dari pelanggan. Informasi yang terdapat pada dataset yaitu sebagai berikut:

a. Pelanggan yang pergi dalam sebulan terakhir yaitu terdapat pada atribut Churn.

b. Layanan yang digunakan setiap pelanggan seperti telepon, multiplelines, internet, online security, online backup, device protection, tech support, serta streaming TV dan movies.

c. Informasi akun pelanggan seperti lama waktu menjadi pelanggan, kontrak, metode pembayaran, penagihan tanpa kertas, tagihan bulanan, dan biaya total.

d. Info demografis tentang pelanggan seperti usia, jenis kelamin, dan apakah pelanggan memiliki pasangan serta tanggungan.

3. Data Preparation (Persiapan Data)

Tahap persiapan data dilakukan untuk membangun dataset akhir yang akan digunakan untuk pemodelan (Fadillah, 2015).

a. Attribute reduction

Atribut customerID dapat dihapus karena tidak diperlukan dalam proses pemodelan.

b. Replace name

Replace dilakukan terhadap record di beberapa atribut dengan isian yang diasumsikan bernilai sama.

Berdasarkan Tabel terdapat beberapa pilihan yaitu 'Yes', 'No', 'No phone service', dan 'No internet service'. Untuk pilihan 'No phone service' dan 'No internet service' diasumsikan bahwa pelanggan tidak menggunakan layanan tersebut sehingga pilihan tersebut akan di-rename menjadi 'No'.

c. Data transformation

Atribut pada dataset yang berbentuk nominal diubah ke dalam bentuk numerik. Sedangkan label Churn tetap dalam bentuk nominal karena dataset akan diterapkan pada algoritme klasifikasi. Hal ini dapat dilihat pada Tabel .

d. Handling missing value

Terdapat 11 missing value pada atribut TotalCharges yang merupakan data biaya yang dibebankan kepada pelanggan. Pada kasus ini masalah tersebut ditangani dengan menghapus record pada baris yang memiliki missing value. Penghapusan dilakukan karena jumlah record yang terdapat missing value tidak sampai $1 \%$ dari jumlah keseluruhan data, sehingga tidak akan memengaruhi hasil pemodelan secara signifikan (Chandranegara, Arifianto, \& Wibowo, 2020).

Dataset akhir setelah dilakukannya tahap preparation yaitu menjadi 7032 baris dengan 20 atribut serta seluruh atribut bertipe numerik dan label bertipe nominal yang dapat dilihat pada Tabel .

4. Modeling (Pemodelan)

Tahap pemodelan dilakukan dengan membandingkan tiga algoritme klasifikasi yaitu logistic regression, decision tree, dan random forest serta ditambahkan dengan metode backward elimination (BE). BE merupakan salah satu metode feature selection yang dimulai dengan mengambil semua prediktor, kemudian dilanjutkan dengan pengurangan variabel yang tidak signifikan hingga akhirnya sampai pada model yang optimal (Golestan \& Hezarkhani, 2018). Dengan demikian, hasil akhir akan menampilkan enam perbandingan dari algoritme yang tidak menggunakan BE dan yang menggunakan $B E$.

Logistic regression merupakan algoritme yang digunakan untuk masalah klasifikasi biner yang pada labelnya hanya terdapat dua nilai. Setiap fitur dikalikan dengan koefisien regresi, kemudian fungsi sigmoid diperkenalkan, dan terakhir nilai dikeluarkan dalam interval 0 sampai 1. Jika nilainya lebih besar dari 0,5 maka label diklasifikasikan sebagai kelas 1 . Jika kurang dari 0,5 maka label diklasifikasikan sebagai kelas 0 (X. Li \& Z. Li, 2019).

Decision tree merupakan diagram aturan pengambilan keputusan yang digunakan untuk mengkategorikan subjek menjadi beberapa kelompok (E. Lee, Kim, \& S. Lee, 2017). Pembuatan pohon keputusan dilakukan berdasarkan pemilihan atribut yang memiliki nilai gain tertinggi berdasarkan nilai entropy atribut sebagai poros atribut klasifikasi (Utami et al., 2020).

Random forest merupakan gabungan yang berasal dari teknik classification and regression tree (CART) yang berbasiskan pohon keputusan. Random forest memprediksi dengan menggabungkan sejumlah pohon. Hasil prediksi random forest dipilih berdasarkan kategori atau kelas yang paling sering muncul sebagai hasil prediksi dari sejumlah pohon klasifikasi (Ullah et al., 2019).

Uji perbandingan dari masing-masing model dilakukan menggunakan split data dengan rasio sebesar 0,8 sebagai data training dan 0,2 sebagai data testing. Rasio tersebut dipilih karena semakin besar data training maka dapat mewakili kumpulan data secara keseluruhan dengan karakteristik yang berbeda (Machine 
Learning, 2020). Dengan demikian, dari 7032 baris dataset didapatkan sebanyak 5625 baris sebagai data training dan 1407 baris sebagai data testing.

5. Evaluation (Evaluasi)

Tahap evaluasi merupakan pengontrolan terhadap pemodelan yang sudah dilakukan untuk mendapatkan hasil yang sesuai dengan tujuan pada tahap business understanding. Pada penelitian ini dilakukan proses evaluasi dengan menggunakan confusion matrix dan nilai area under curve (AUC). Confusion matrix memberikan representasi ringkasan hasil prediksi dengan indeks true positive (TP), true negative (TN), false positive (FP), dan false negative (FN) (Zhu, Idemudia, \& Feng, 2019).

Tabel 4. Confusion Matrix

\begin{tabular}{ccc}
\hline & True No & True Yes \\
\hline Prediction No & TN & FN \\
Prediction Yes & FP & TP \\
\hline Sumber: Bisri \& Rachmatika & $(2019)$
\end{tabular}

Dimana:

TP $=$ True Positive (data diprediksi positif dan aktual positif)

FP = False Positive (data diprediksi positif dan aktual negatif)

$\mathrm{FN}$ = False Negative (data diprediksi negatif dan aktual positif)

TN = True Negative (data diprediksi negatif dan aktual negatif)

Dari penyajian tabel confusion matrix pada Tabel 4 dapat dilakukan perhitungan untuk mengetahui nilai accuracy dan recall dengan persamaan sebagai berikut.

$$
\begin{aligned}
& \text { Accuracy }=\frac{T P+T N}{T P+F P+F N+T N} \\
& \text { Recall }=\frac{T P}{T P+F N}
\end{aligned}
$$

Sedangkan nilai AUC diperlukan untuk mengetahui kriteria sebuah pemodelan dari teknik klasifikasi yang telah dilakukan (Bisri \& Rachmatika, 2019). Penilaian AUC ditentukan dengan kriteria pernyataan keberhasilan sebagai berikut.

Tabel 5. Kriteria Pemodelan

\begin{tabular}{cc}
\hline Nilai & Kriteria \\
\hline $0,90-1,00$ & Sangat baik (excellent \\
$0,80-0,90$ & Classification) \\
$0,70-0,80$ & Waik (good classification) \\
$0,60-0,70$ & Buruk (fair classification) \\
$<0,60$ & Gagal (failure) \\
\hline
\end{tabular}

Sumber: Bisri \& Rachmatika (2019)

a. Logistic Regression

Hasil pemodelan dengan logistic regression ditunjukkan pada Tabel 6. Berikut merupakan tabel confusion matrix hasil pemodelan algoritme logistic regression.
Tabel 7. Confusion Matrix Logistic Regression

\begin{tabular}{lcc}
\hline & True No & True Yes \\
\hline Prediction No & 940 & 161 \\
Prediction Yes & 93 & 213 \\
\hline
\end{tabular}

Berdasarkan Tabel 7, diperoleh nilai accuracy dan recall sebagai berikut.

$$
\begin{aligned}
& \text { Accuracy }=\frac{213+940}{213+93+161+940} \\
& =\frac{1153}{1407}=0,8195=81,95 \% \\
& \text { Recall }=\frac{213}{213+161}=\frac{213}{374}=0,5695=56,95 \%
\end{aligned}
$$

Nilai AUC pada model logistic regression yaitu sebesar 0,851 .

b. Decision Tree

Hasil pemodelan dengan decision tree ditunjukkan pada Gambar 2. Berikut merupakan tabel confusion matrix hasil pemodelan algoritme decision tree.

Tabel 8. Confusion Matrix Decision Tree

\begin{tabular}{lcc}
\hline & True No & True Yes \\
\hline Prediction No & 889 & 181 \\
Prediction Yes & 144 & 193 \\
\hline
\end{tabular}

Berdasarkan Tabel 8, diperoleh nilai accuracy dan recall sebagai berikut.

$$
\begin{gathered}
\text { Accuracy }=\frac{193+889}{193+144+181+889} \\
=\frac{1082}{1407}=0,7690=76,90 \%
\end{gathered}
$$

Recall $=\frac{193}{193+181}=\frac{193}{374}=0,5160=51,60 \%$

Nilai AUC pada model decision tree yaitu sebesar 0,779.

c. Random Forest

Hasil pemodelan random forest menghasilkan banyak tree, salah satunya ditunjukkan pada Gambar 3. Berikut merupakan tabel confusion matrix hasil pemodelan algoritme random forest.

Tabel 9. Confusion Matrix Random Forest

\begin{tabular}{lcc}
\hline & True No & True Yes \\
\hline Prediction No & 984 & 230 \\
Prediction Yes & 49 & 144 \\
\hline
\end{tabular}

Berdasarkan Tabel 9, diperoleh nilai
accuracy dan recall sebagai berikut.

$$
\begin{array}{r}
\text { Accuracy }=\frac{144+984}{144+49+230+984} \\
=\frac{1128}{1407}=0,8017=80,17 \%
\end{array}
$$

$$
\text { Recall }=\frac{144}{144+230}=\frac{144}{374}=0,3850=38,50 \%
$$

Nilai AUC pada model random forest yaitu sebesar 0,847. 
d. Logistic Regression $+B E$

Hasil pemodelan logistic regression dengan BE ditunjukkan pada Tabel 10.

Berikut merupakan tabel confusion matrix hasil pemodelan algoritme logistic regression dengan $\mathrm{BE}$.

Tabel 11. Confusion Matrix Logistic Regression dengan $\mathrm{BE}$

\begin{tabular}{lcc}
\hline & True No & True Yes \\
\hline Prediction No & 943 & 160 \\
Prediction Yes & 90 & 214 \\
\hline
\end{tabular}

Berdasarkan Tabel 11, diperoleh nilai accuracy dan recall sebagai berikut.

$$
\begin{aligned}
& \text { Accuracy }=\frac{214+943}{214+90+160+943} \\
& =\frac{1157}{1407}=0,8223=82,23 \% \\
& \text { Recall }=\frac{214}{214+160}=\frac{214}{374}=0,5722=57,22 \%
\end{aligned}
$$

Nilai AUC pada model logistic regression dengan BE yaitu sebesar 0,853.

e. Decision Tree $+B E$

Hasil pemodelan decision tree dengan $\mathrm{BE}$ ditunjukkan pada Tabel 12. Berikut merupakan tabel confusion matrix hasil pemodelan algoritme decision tree dengan BE.

Tabel 13. Confusion Matrix Decision Tree dengan $\mathrm{BE}$

\begin{tabular}{lcc}
\hline & True No & True Yes \\
\hline Prediction No & 972 & 222 \\
Prediction Yes & 61 & 152
\end{tabular}

Berdasarkan Tabel 13, diperoleh nilai accuracy dan recall sebagai berikut.

$$
\begin{gathered}
\text { Accuracy }=\frac{152+972}{152+61+222+972} \\
=\frac{1124}{1407}=0,7989=79,89 \% \\
\text { Recall }=\frac{152}{152+222}=\frac{152}{374}=0,4064=40,64 \%
\end{gathered}
$$

Nilai AUC pada model decision tree dengan BE yaitu sebesar 0,825 .

f. Random Forest $+B E$

Hasil pemodelan random forest dengan $\mathrm{BE}$ ditunjukkan pada Tabel 14 . Berikut merupakan tabel confusion matrix hasil pemodelan algoritme random forest dengan $\mathrm{BE}$.

Tabel 15. Confusion Matrix Random Forest dengan $\mathrm{BE}$

\begin{tabular}{lcc}
\hline & True No & True Yes \\
\hline Prediction No & 962 & 198 \\
\hline Prediction Yes & 71 & 176 \\
\hline
\end{tabular}

Berdasarkan Tabel 15, diperoleh nilai accuracy dan recall sebagai berikut.

$$
\begin{gathered}
\text { Accuracy }=\frac{176+962}{176+71+198+962} \\
=\frac{1138}{1407}=0,8088=80,88 \% \\
\text { Recall }=\frac{176}{176+198}=\frac{176}{374}=0,4706=47,06 \%
\end{gathered}
$$

Nilai AUC pada model random forest dengan $B E$ yaitu sebesar 0,851 .

Berdasarkan enam pengujian yang telah dilakukan, dapat dilihat rekap nilai accuracy, recall, dan AUC dari masing-masing pemodelan

\begin{tabular}{|c|c|c|c|}
\hline & Accuracy & Recall & AUC \\
\hline \multicolumn{4}{|c|}{ Penelitian terdahulu } \\
\hline LogReg & $79 \%$ & $56 \%$ & - \\
\hline RF & $80 \%$ & $52 \%$ & - \\
\hline DT & $87.03 \%$ & $96 \%$ & - \\
\hline \multicolumn{4}{|c|}{ Penelitian sekarang tanpa BE } \\
\hline LogReg & $81,95 \%$ & $56,95 \%$ & 0,851 \\
\hline RF & $80,17 \%$ & $38,50 \%$ & 0,847 \\
\hline DT & $76,90 \%$ & $51,60 \%$ & 0,779 \\
\hline \multicolumn{4}{|c|}{ Penelitian sekarang + BE } \\
\hline LogReg & $82,23 \%$ & $57,22 \%$ & 0,853 \\
\hline $\mathbf{R F}$ & $80,88 \%$ & $47,06 \%$ & 0,851 \\
\hline DT & $79,89 \%$ & $40,64 \%$ & 0,825 \\
\hline
\end{tabular}
pada gambar 11. Pemodelan menggunakan logistic regression dengan $\mathrm{BE}$ memperoleh accuracy, recall, dan AUC dengan nilai tertinggi dari pemodelan lainnya.

Berikut perbandingan hasil dengan penelitian terdahulu.

Tabel 16. Perbandingan dengan Penelitian Terdahulu

\section{Deployment (Penyebaran)}

Tahap penyebaran merupakan bentuk laporan (paper) mengenai informasi yang didapat berdasarkan hasil pengamatan dan analisis perbandingan algoritme teknik klasifikasi untuk prediksi customer churn. Selain itu, penyebaran ini juga dapat digunakan sebagai bahan referensi untuk penelitian selanjutnya.

\section{KESIMPULAN}

Berdasarkan penelitian yang telah dilakukan, diperoleh bahwa algoritme logistic regression dengan backward elimination dapat digunakan untuk memprediksi customer churn. Nilai akurasi yang diperoleh dengan algoritme ini yaitu sebesar $82,23 \%$ yang merupakan nilai akurasi tertinggi dari dua algoritme lainnya. Nilai recall yang diperoleh menunjukkan $57,22 \%$ bahwa pelanggan terklasifikasi benar melakukan churn. Nilai AUC yang didapatkan sebesar 0,853, hal ini berarti bahwa pemodelan teknik klasifikasi yang dilakukan berhasil dengan kriteria good classification.

\section{REFERENSI}

Bisri, A., \& Rachmatika, R. (2019). Integrasi Gradient Boosted Trees dengan SMOTE dan Bagging untuk Deteksi Kelulusan 
Mahasiswa. Jurnal Nasional Teknik Elektro Dan Teknologi Informasi (JNTETI), 8(4), 309-314. https://doi.org/10.22146/jnteti.v8i4.529

Chandranegara, D. R., Arifianto, S., \& Wibowo, H. (2020). Analisa data pesawat terbang menggunakan metode elimination void data dan smoothing data. Jurnal POROS TEKNIK, 12(1), 1-7.

Drajana, I. C. R. (2019). Prediksi Loyalitas Pelanggan IndiHome dengan Metode KNearest Neighbor. Jurnal Sistem Informasi Dan Teknik Komputer, 4(2), 100-103. https://doi.org/10.4249/scholarpedia.1883

Fadillah, A. P. (2015). Penerapan Metode CRISP-DM untuk Prediksi Kelulusan Studi Mahasiswa Menempuh Mata Kuliah (Studi Kasus Universitas XYZ). Jurnal Teknik Informatika Dan Sistem Informasi, 1(3), 260-270.

https://doi.org/10.28932/jutisi.v1i3.406

Golestan, F. D., \& Hezarkhani, A. (2018). Quadratic investigation of geochemical distribution by backward elimination approach at Glojeh epithermal $\mathrm{Au}(\mathrm{Ag})$ polymetallic mineralization, NW Iran. Journal of Central South University, 25(2), 342-356. https://doi.org/10.1007/s11771018-3741-8

Herawati, M., Wibowo, I. L., \& Mukhlash, I. (2016). Prediksi Customer Churn Menggunakan Algoritma Fuzzy Iterative Dichotomiser 3. Limits: Journal of Mathematics and Its Applications, 13(1), 23-35.

https://doi.org/10.12962/j1829605x.v13i1. 1913

Kaggle. (2018). Telco Customer Churn [Data file]. San Francisco: Author.

Kavitha, V., Kumar, G. H., Kumar, S. M., \& Harish, M. (2020). Churn Prediction of Customer in Telecom Industry using Machine Learning Algorithms. International Journal of Engineering Research and Technology (IJERT), 9(5), 181-184.

https://doi.org/10.17577/ijertv9is050022

Kementerian Komunikasi dan Informatika. (2018). Analisa Industri Telekomunikasi Indonesia untuk Mendukung Efisiensi. https://balitbangsdm.kominfo.go.id/publika si 465_3 199

Khumaidi, A. (2020). Data Mining for Predicting the Amount of Coffee Production Using CRISP-DM Method. Jurnal Techno Nusa Mandiri, 17(1), 1-8. https://doi.org/10.33480/techno.v17i1.124 0

Lee, E. B., Kim, J., \& Lee, S. G. (2017)
Predicting customer churn in mobile industry using data mining technology. Industrial Management and Data Systems, 117(1), 90-109. https://doi.org/10.1108/IMDS-12-20150509

Li, X., \& Li, Z. (2019). A Hybrid Prediction Model for E-Commerce Customer Churn Based on Logistic Regression and Extreme Gradient Boosting Algorithm. International Information and Engineering Technology Association (IIETA), 24(5), 525-530. https://doi.org/10.18280/isi.240510

Machine Learning.

(2020) Https://Developers.Google.Com/MachineLearning/Crash-Course/Training-andTest-Sets/Splitting-Data.

Pamina, J., Beschi Raja, J., Sathya Bama, S., Soundarya, S., Sruthi, M. S., Kiruthika, S., Aiswaryadevi, V. J., \& Priyanka, G. (2019). An Effective Classifier for Predicting Churn in Telecommunication. Journal of Advanced Research in Dynamical and Control Systems, 11(1), 221-229.

Ullah, I., Raza, B., Malik, A. K., Imran, M., Islam, S. U., \& Kim, S. W. (2019). A Churn Prediction Model Using Random Forest: Analysis of Machine Learning Techniques for Churn Prediction and Factor Identification in Telecom Sector. IEEE Access, 7, 60134-60149. https://doi.org/10.1109/ACCESS.2019.291 4999

Utami, Y. T., Shofiana, D. A., \& Heningtyas, Y. (2020). Penerapan Algoritma C4.5 Untuk Prediksi Churn Rate Pengguna Jasa Telekomunikasi. Jurnal Komputasi, 8(2), 69-76.

Wardani, N. W., \& Ariasih, N. K. (2019). Analisa Komparasi Algoritma Decision Tree C4 . 5 dan Naïve Bayes untuk Prediksi Churn Berdasarkan Kelas Pelanggan Retail. International Journal of Natural Sciences and Engineering, 3(3), 103-112.

Yulianti. (2018). Metode Data Mining untuk Prediksi Churn Pelanggan. Jurnal ICT Akademi Telkom Jakarta, 17, 46-52.

Zhu, C., Idemudia, C. U., \& Feng, W. (2019). Improved logistic regression model for diabetes prediction by integrating PCA and $\mathrm{K}$-means techniques. Informatics in Medicine Unlocked, 17, 1-7. https://doi.org/10.1016/j.imu.2019.100179 
Tabel 1. Dataset Pelanggan Telekomunikasi

\begin{tabular}{ccccccccc}
\hline customerID & gender & SeniorCitizen & Partner & Dependents & tenure & PhoneService & $\ldots$ & Churn \\
\hline 7590-VHVEG & Female & 0 & Yes & No & 1 & No & $\ldots$ & No \\
5575-GNVDE & Male & 0 & No & No & 34 & Yes & $\ldots$ & No \\
3668-QPYBK & Male & 0 & No & No & 2 & Yes & $\ldots$ & Yes \\
7795-CFOCW & Male & 0 & No & No & 45 & No & $\ldots$ & No \\
9237-HQITU & Female & 0 & No & No & 2 & Yes & $\ldots$ & Yes \\
9305-CDSKC & Female & 0 & No & No & 8 & Yes & $\ldots$ & Yes \\
1452-KIOVK & Male & 0 & No & Yes & 22 & Yes & $\ldots$ & No \\
6713-OKOMC & Female & 0 & No & No & 10 & No & $\ldots$ & No \\
$\ldots$ & $\ldots$ & $\ldots$ & $\ldots$ & $\ldots$ & $\ldots$ & $\ldots$ & $\ldots$ & $\ldots$ \\
3186-AJIEK & Male & 0 & No & No & 66 & Yes & $\ldots$ & No \\
\hline
\end{tabular}

Tabel 2. Atribut Yang Akan Di-Rename

\begin{tabular}{|c|c|c|c|c|c|c|}
\hline MultipleLines & OnlineSecurity & OnlineBackup & DeviceProtection & TechSupport & Streaming TV & StreamingMovies \\
\hline No & No & No & Yes & Yes & No & No \\
\hline No & No & Yes & Yes & No & No & Yes \\
\hline $\begin{array}{c}\text { No Phone } \\
\text { Service }\end{array}$ & No & No & Yes & No & No & Yes \\
\hline No & $\begin{array}{c}\text { No Internet } \\
\text { Service }\end{array}$ & $\begin{array}{c}\text { No Internet } \\
\text { Service }\end{array}$ & No Internet Service & $\begin{array}{c}\text { No Internet } \\
\text { Service }\end{array}$ & $\begin{array}{c}\text { No Internet } \\
\text { Service }\end{array}$ & No Internet Service \\
\hline No & $\begin{array}{c}\text { No Internet } \\
\text { Service }\end{array}$ & $\begin{array}{c}\text { No Internet } \\
\text { Service }\end{array}$ & No Internet Service & $\begin{array}{c}\text { No Internet } \\
\text { Service }\end{array}$ & $\begin{array}{c}\text { No Internet } \\
\text { Service }\end{array}$ & No Internet Service \\
\hline Yes & No & Yes & No & Yes & No & No \\
\hline No & Yes & Yes & No & Yes & No & No \\
\hline
\end{tabular}

Tabel 3. Dataset Akhir

\begin{tabular}{|c|c|c|c|c|c|c|c|c|c|c|}
\hline Churn & $\begin{array}{c}\text { Multiple } \\
\text { Lines }\end{array}$ & $\begin{array}{l}\text { Online } \\
\text { Security }\end{array}$ & $\begin{array}{l}\text { Online } \\
\text { Backup }\end{array}$ & $\begin{array}{c}\text { Device } \\
\text { Protection }\end{array}$ & $\begin{array}{c}\text { Tech } \\
\text { Support }\end{array}$ & $\begin{array}{l}\text { Stream- } \\
\text { ingTV }\end{array}$ & $\begin{array}{c}\text { Streaming } \\
\text { Movies }\end{array}$ & gender & $\cdots$ & $\begin{array}{c}\text { Total } \\
\text { Charges }\end{array}$ \\
\hline No & 0 & 0 & 0 & 0 & 0 & 0 & 0 & 0 & $\ldots$ & 29.85 \\
\hline No & 0 & 1 & 1 & 1 & 0 & 0 & 0 & 1 & $\ldots$ & 1889.5 \\
\hline Yes & 0 & 1 & 0 & 0 & 0 & 0 & 0 & 1 & $\ldots$ & 108.15 \\
\hline No & 0 & 1 & 1 & 1 & 1 & 0 & 0 & 1 & $\ldots$ & 1840.75 \\
\hline Yes & 0 & 0 & 1 & 0 & 0 & 0 & 0 & 1 & $\ldots$ & 151.65 \\
\hline Yes & 1 & 0 & 1 & 1 & 0 & 1 & 1 & 1 & $\ldots$ & 820.5 \\
\hline No & 1 & 0 & 0 & 0 & 0 & 1 & 0 & 1 & $\ldots$ & 1949.4 \\
\hline No & 0 & 1 & 1 & 0 & 0 & 0 & 0 & 1 & $\ldots$ & 301.9 \\
\hline$\ldots$ & $\ldots$ & $\cdots$ & $\ldots$ & $\cdots$ & $\cdots$ & $\cdots$ & $\cdots$ & $\ldots$ & $\ldots$ & $\ldots$ \\
\hline No & 0 & 1 & 1 & 1 & 1 & 1 & 1 & 1 & $\ldots$ & 6844.5 \\
\hline
\end{tabular}

Tabel 6. Hasil Pemodelan Logistic Regression

\begin{tabular}{|c|c|c|c|c|c|}
\hline Attribute & Coefficient & Std. Coefficient & Std. Error & z-Value & p-Value \\
\hline MultipleLines & 0.074 & 0.037 & 0.092 & 0.810 & 0.418 \\
\hline OnlineSecurity & -0.558 & -0.252 & 0.096 & -5.820 & 0.000 \\
\hline OnlineBackup & 0.253 & 0.121 & 0.088 & 2.884 & 0.004 \\
\hline DeviceProtection & -0.241 & -0.115 & 0.090 & -2.667 & 0.008 \\
\hline TechSupport & -0.468 & -0.213 & 0.095 & -4.910 & 0.000 \\
\hline StreamingTV & -0.130 & -0.063 & 0.097 & -1.340 & 0.180 \\
\hline StreamingMovies & -0.017 & -0.008 & 0.097 & -0.171 & 0.864 \\
\hline gender & -0.026 & -0.013 & 0.072 & -0.354 & 0.723 \\
\hline Partner & -0.005 & -0.003 & 0.086 & -0.058 & 0.953 \\
\hline Dependents & -0.155 & -0.071 & 0.100 & -1.548 & 0.122 \\
\hline PhoneService & -1.239 & -0.366 & 0.166 & -7.472 & 0.000 \\
\hline InternetService & -0.041 & -0.030 & 0.073 & -0.562 & 0.574 \\
\hline Contract & -0.754 & -0.627 & 0.087 & -8.648 & 0 \\
\hline PaperlessBilling & -0.422 & -0.208 & 0.083 & -5.109 & 0.000 \\
\hline PaymentMethod & -0.094 & -0.108 & 0.034 & -2.767 & 0.006 \\
\hline SeniorCitizen & 0.192 & 0.071 & 0.094 & 2.038 & 0.042 \\
\hline tenure & -0.061 & -1.496 & 0.007 & -8.769 & 0 \\
\hline MonthlyCharges & 0.030 & 0.913 & 0.003 & 10.478 & 0 \\
\hline TotalCharges & 0.000 & 0.780 & 0.000 & 4.352 & 0.000 \\
\hline Intercept & -0.300 & -1.756 & 0.216 & -1.391 & 0.164 \\
\hline
\end{tabular}




\section{Tree}

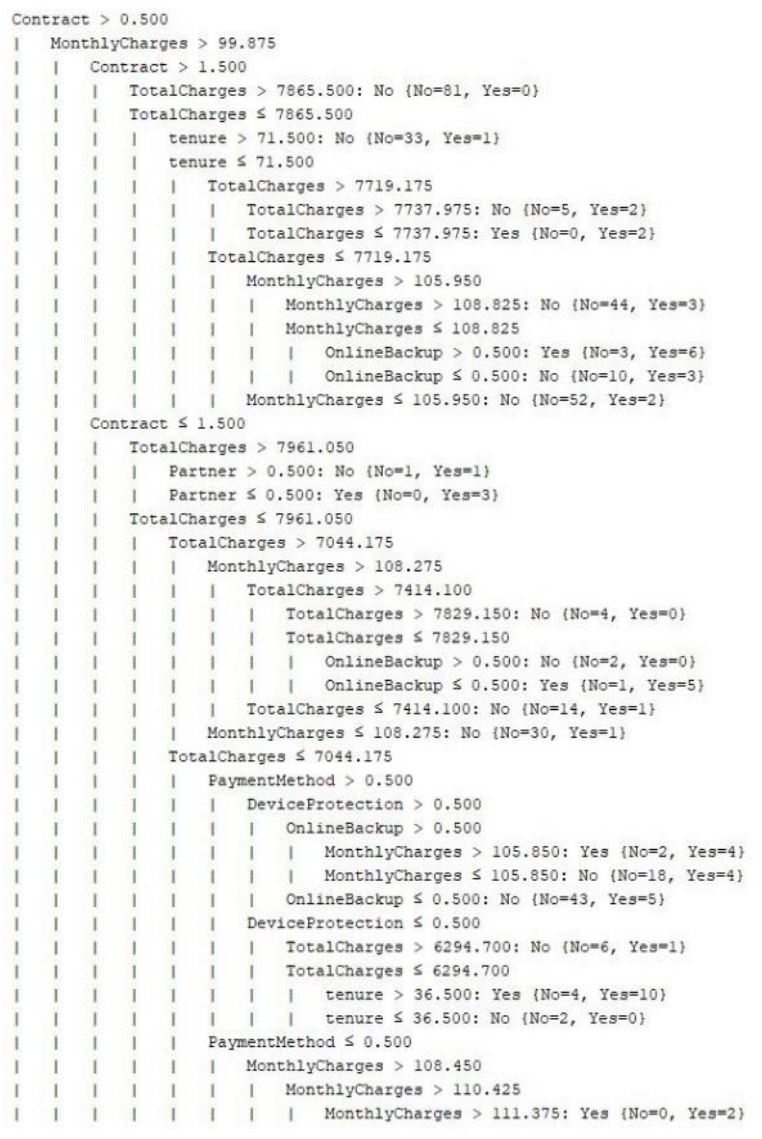

Gambar 2. Hasil Pemodelan Decision Tree

\section{Tree}

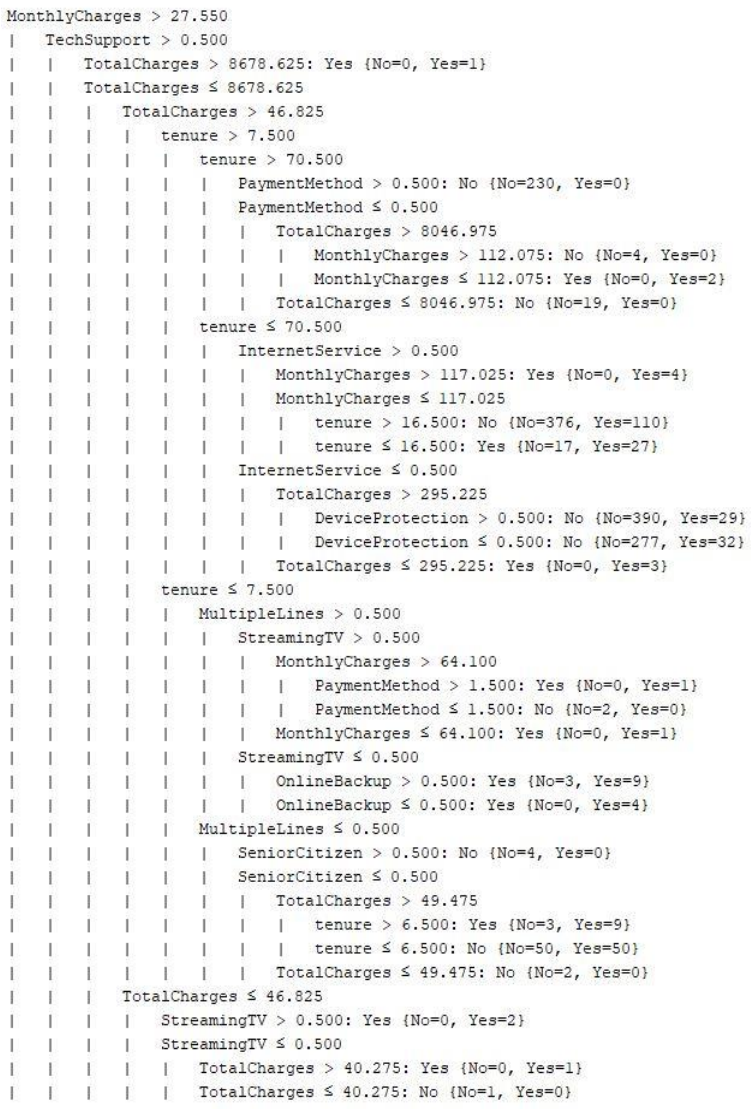

Gambar 3. Salah Satu Tree Hasil Pemodelan Random Forest
Tabel 10. Hasil Pemodelan Logistic Regression dengan BE

\begin{tabular}{lc}
\hline \multicolumn{1}{c}{ Attribute } & Weight \\
\hline MultipleLines & 1 \\
\hline OnlineSecurity & 1 \\
\hline OnlineBackup & 1 \\
\hline DeviceProtection & 1 \\
\hline TechSupport & 1 \\
\hline StreamingTV & 1 \\
\hline StreamingMovies & 1 \\
\hline gender & 1 \\
\hline Partner & 1 \\
\hline Dependents & 0 \\
\hline PhoneService & 1 \\
\hline InternetService & 1 \\
\hline Contract & 1 \\
\hline PaperlessBilling & 1 \\
\hline PaymentMethod & 1 \\
\hline SeniorCitizen & 1 \\
\hline tenure & 1 \\
\hline MonthlyCharges & 1 \\
\hline TotalCharges & 0 \\
\hline
\end{tabular}

Tabel 12. Hasil Pemodelan Decision Tree dengan BE

\begin{tabular}{lc}
\hline \multicolumn{1}{c}{ Attribute } & Weight \\
\hline MultipleLines & 1 \\
\hline OnlineSecurity & 1 \\
\hline OnlineBackup & 1 \\
\hline DeviceProtection & 1 \\
\hline TechSupport & 1 \\
\hline StreamingTV & 1 \\
\hline StreamingMovies & 1 \\
\hline gender & 1 \\
\hline Partner & 1 \\
\hline Dependents & 1 \\
\hline PhoneService & 1 \\
\hline InternetService & 1 \\
\hline Contract & 0 \\
\hline PaperlessBilling & 1 \\
\hline PaymentMethod & 1 \\
\hline SeniorCitizen & 1 \\
\hline tenure & 1 \\
\hline MonthlyCharges & 1 \\
\hline TotalCharges & 1 \\
\hline
\end{tabular}

Tabel 14. Hasil Pemodelan Random Forest dengan BE

\begin{tabular}{lc}
\hline \multicolumn{1}{c}{ Attribute } & Weight \\
\hline MultipleLines & 1 \\
\hline OnlineSecurity & 1 \\
\hline OnlineBackup & 1 \\
\hline DeviceProtection & 1 \\
\hline TechSupport & 0 \\
\hline StreamingTV & 1 \\
\hline StreamingMovies & 1 \\
\hline gender & 1 \\
\hline Partner & 1 \\
\hline Dependents & 0 \\
\hline PhoneService & 1 \\
\hline InternetService & 1 \\
\hline Contract & 1 \\
\hline PaperlessBilling & 1 \\
\hline PaymentMethod & 1 \\
\hline SeniorCitizen & 1 \\
\hline tenure & 1 \\
\hline MonthlyCharges & 1 \\
\hline TotalCharges & 1 \\
\hline
\end{tabular}




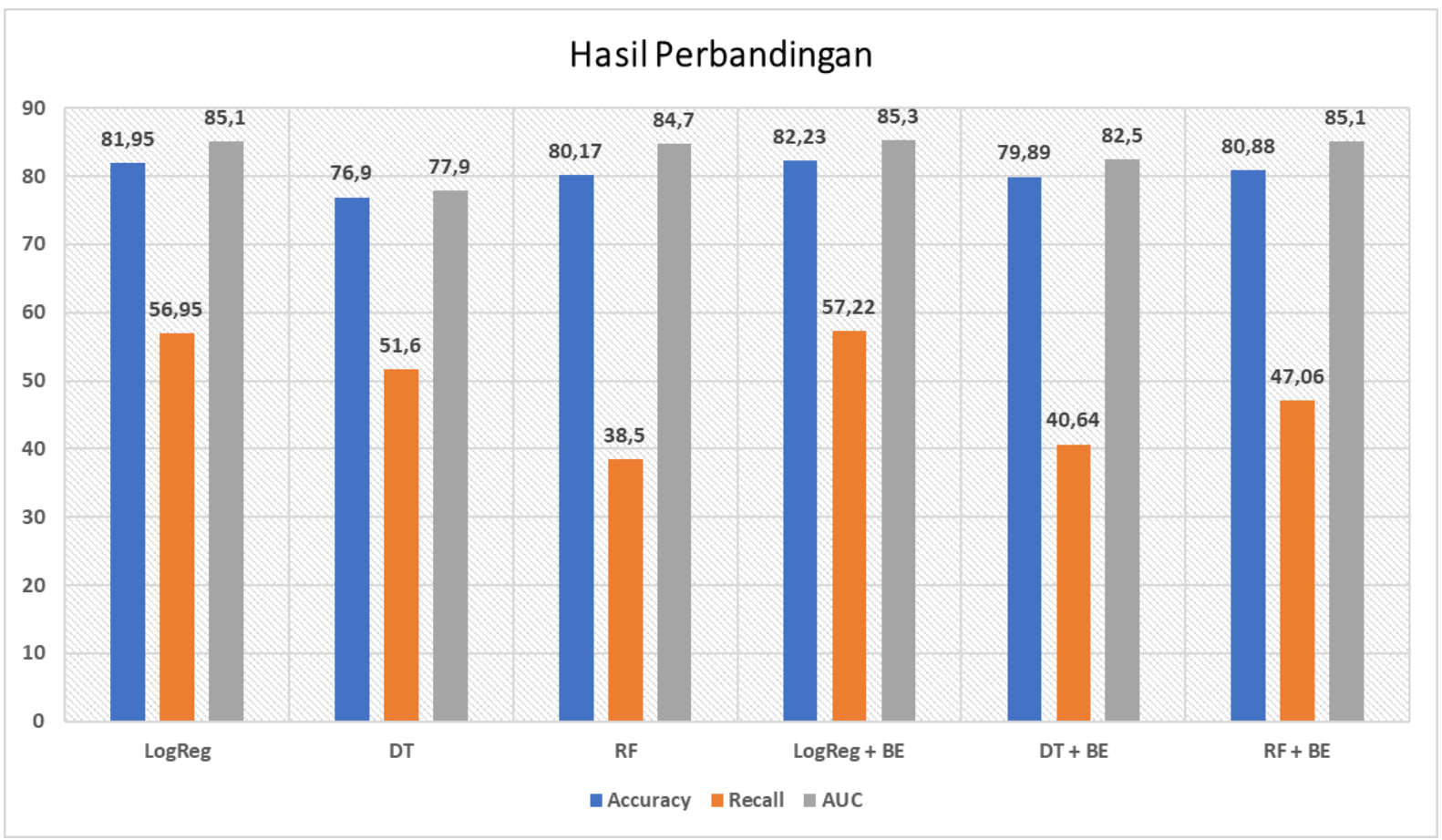

Gambar 4. Hasil Perbandingan Pemodelan 